\title{
The linguistic Proposals of Juan de Valdés, their Contribution to Translation and Influence on the Spanish Version of the 'Bear's Bible' (Biblia del Oso)
}

\author{
Juan Luis Monreal Pérez \\ Universidad de Murcia. Departamento de Filosofía \\ jlmonreal@um.es
}

https://dx.doi.org/10.12795/futhark.2013.i08.11

\begin{abstract}
:
Juan de Valdés should be included in the list of significant Spanish humanists, in that his development both at a personal level and as a man of letters are clearly marked by Humanism, cultivating all the values pertinent to this movement. Language and literature were always permanent features in the humanistic culture of Valdés, especially in his contribution to the development of the Spanish language through his main work Dialogue of Language in which he formulates important Linguistic Proposals. The knowledge of language shown by Valdés in this work and the academic training received in Latin, Greek and Hebrew at Alcalá University show him fit to carry out translation tasks by which he continued the humanist tradition in this field and joined the list of humanist reformers who also undertook this difficult role. Specifically, his work in the field of translation and his Linguistic Proposals influenced the first complete version of the Bible in Spanish (1569) of Casiodoro de la Reina, known as the Bear's Bible (Biblia del Oso), because of the printer's seal. This was a milestone, not only because it was the first complete version of the Bible in Castilian, but also because it established linguistic and hermeneutic canons that passed into the humanistic translation tradition and were also supported by the majority of reformers of the sixteenth century exile, The Casiodoro de la Reina translation of the Biblewas particularly influenced by the work and translations of Juan de Valdés.

Key words: Humanism, Linguist, Philology, Erasmism, 'Bear's Bible'
\end{abstract}

Resumen: Juan de Valdés debe ser incluido en la lista de humanistas españoles relevantes, en cuanto que su trayectoria personal y de hombre de letras está marcada por un claro humanismo, cultivando todos los valores propios de esta corriente. La lengua y la literatura siempre fueron para Val- 
dés elementos permanentes en su cultura humanista contribuyendo especialmente al desarrollo de la lengua española mediante su obra principal el Diálogo de la lengua en la que formulasignificativas Propuestas lingüísticas. Con el conocimiento de la lengua que Valdés muestra en esta obra y con la formación académica que recibe en Alcalá en latín, griego y hebreo está preparado para llevar a cabo tareas de traducción con las que Valdés continúa la tradición humanista en este campo y se suma a la lista de humanistas reformadores que acometieron también este difícil trabajo. Concretamente, su labor en el campo de la traducción y sus Propuestas Lingüísticas tuvieron influencia en la primera versión completa de la Biblia en lengua española (1569) de Casiodoro de la Reina, denominada la Biblia del Oso, porque tal era el lema del impresor.. Ésta supuso un hito no solo por ser la primera versión castellana de la Biblia, sino porque también establece unos cánones lingüísticos y hermeneúticos que se insertan en la tradición traductológica humanista y también avalados por la mayoría de los reformistas del exilio del siglo XVI. En la traducción de la Biblia de Casiodoro de la Reina influyó especialmente la obra y los trabajos de traducción de Juan de Valdés.

Descriptores: Humanismo, Lingüista, Filólogo, Erasmismo, Biblia del Oso

\section{INTRODUCTION}

Notonly are there gaps in our knowledge of the biography of Juan de Valdés, but also in the development, spread, influence and interpretation of his writings (Cf. Barbolani, 2006: 35-36; Alcalá, 1997: IX). A typical example of such gaps is that arising from certain features of the interpretation of Valdés' work the Dialogue of Language (1535) in that this work has some little understood aspects that, logically, give rise to all manner of conjectures and interpretations. However, this does not prevent discovery and examination of its contribution to the Spanish language. Specifically, his Linguistic Proposals, contained in the Dialogue of Language, direct his work towards the field of translation and influenced the first complete version of the Bible in Spanish, known as the Bear's Bible (Biblia del Oso).

\section{JUAN DE VALDÉS AND HIS HUMANIST BACKGROUND}

Juan de Valdés should be included in the list of significant Spanish humanist Erasmists ${ }^{1}$, regardless of the fact that in the second half of his life

The label of humanistErasmist is given in Spain to those Spanish humanists influenced by Erasmus of Rotterdam and, among others, worthy of mention are Cardenal Cisneros, Nebrija, Luis Vives, and fray Luis de León. Alongside the name of 
he lived in Italy with all that that entailed for the development of his thought and writings.

Two facets of Juan de Valdés are of especial interest: his role as humanist and his role as man of letters. As for the former, his life is clearly marked by a pronounced humanism, developing all the values pertinent to this movement, although with reference to his thinking on religion we will never know the exact boundaries within which he moved. In his opinion, Church reform was central for the recovery of a religious climate in the Church as a whole.

The second facet to highlight is the background of Juan de Valdés as a man of letters. Language and literature always played a fundamental part in his humanist culture. It was to be in his time in Italy that he was to take especial interest in the Spanish language, writing the work Dialogue of Language.

\section{THE CASTILIAN LANGUAGE OF JUAN DE VALDÉS AND THE ITALIAN INFLUENCE}

It would be difficult to understand the spirited defence that Valdés makes for the Spanish language were it not taken into account, among other things, that his native or mother tongue was Spanish. This is the language spoken in his family environment, his schooling and early social life, the language of his university education at Alcalá University and the dominant language providing a vehicle for his literary production (Cf. Barbolani, 2006: 17).

While it is true that Valdés knew other languages, both classical and romance, these were languages learned after his mother tongue of Castilian. His basic and University education contributed as much to this as did his stay in Italy.

The use of the Castilian tongue was so entrenched in Valdés that his first work, Dialogue of Christian Doctrine, written at the height of Erasmist influence in Alcalá, was in the vernacular. Valdés had no intention of entering into the question of the Spanish language in this work, a task he left for the later Dialogue of Language, but rather desired to use that language as he understood it. This work already adopts the Erasmus colloquium and, we perceive that this is not only to reflect Erasmus' influence in his writings, but also because this literary genus allows use of the instrument of the Spanish language at its most lively, fresh, direct and simple (Cf. Bataillon, 1986: 346).

Juan de Valdés is that of his brother, Alfonso Valdés (1492-1532), an eminent Erasmistwho remained faithful throughout his life to the reformist tradition and, for a while, undertook the important role of secretary to the Emperor Charles V. 
Valdés' time in Rome marked his development from the perspective of the use of a language. Here his interest and involvement in language in general grew (questione della lingua) and especially that of the common tongue (lingua volgare). There are two main reasons for Valdés' interest in this issue: firstly the interest he already had from his youth, encouraged by the family and social climate in which he had grown up, the secular reading matter in Spanishread as a boy and his education in arts and letters that inculcated good style and expression in the vernacular. The second reason stems from the cultural climate in Italy at that moment, quite stirred up by the questione della linguaand the lingua volgare, still under the influence of Bembo's recently published work Prose della volgar lingua (1525).

\section{LINGUISTIC PROPOSALS OF JUAN DE VALDÉS}

In his work Dialogue of Language, Valdés regrets the state of the Spanish language, wishing, for example, there were works of sufficient level of perfection that could serve as a guide and have the necessary authority to correct language abuses. However, his attitude does not restrict itself to mere recognition of this situation and he wishes to go further in the search for a perfection that the Spanish language clamours. To this end he presents us with various Linguistic Proposals aiming to improve Spanish, the following of which are the most significant:

\section{1- Use of sayings.}

Valdés proposes the use of ancient sayings as genuine patrimony of real language in the face of the lack of good works and authors to mark the way towards perfection in the Castilian tongue. Through his love and appreciation of sayings, Valdés shows his attraction to popular language. They express a plain style and conciseness of expression that form the natural traits of linguistic perfection (Cf.Valdés, 1997: 159-160).

In coherence with this liking for clarity and simplicity, Valdés criticizes any search for perfection via the use of Latinates and esoteric language and takes as linguistic ideal a natural Latin, far removed from that written in an obscurantist style and containing expressions not in common use (Cf.Valdés, 1997: 246-247).

In making recourse to sayings, Valdés is aware of the connection to a specific literary tradition that, both in the past, in Mediaeval times, and in the present has been effective and successful in concrete ways and in general lines has also enriched language as an instrument of communication, as did Erasmus in his Adagia (Cf. Lapesa, 1974: 15). 


\section{2- Model to be followed for a more correct use of language.}

According to Valdés, the development and improvement of the Spanish language should be achieved by valuing use over grammar, in that the former provides specific forms of linguistic construction. Thus, Valdés, a pragmatist rather than a grammarian, turns to the good use of language as manifested in sayings and polite speech (Cf. Valdés, 1997: 156, 215).

\section{3- Style in written and spoken language should be natural and without affectation.}

Valdés recommends care with style. He believes language use does not mean neglect of the care with which art is created in that the characteristics defining it should be guided by style as described in his work Dialogue of Language. Usage and art are therefore not incompatible terms, but rather should be integrated in the way of speaking and writing (Cf. Valdés, 1997: 241 y 244).

The stout defence that Valdés makes for a natural style, leads him to criticize all that is foreign to this way of understanding writing, criticizing works and authors that he knew well and that diverged from the simple style he advocates (Cf. Terracini, 1993: 160).

\section{4-The best option for spoken and written language is that which follows the courtly model.}

Valdés believed that courtly and educated speech should be used so as not to fall into vulgarity; that is, to not confuse popular language and use of sayings with badly spoken or written language. In contrast to the latter, he advocates educated, courtly speech such as that spoken by learned and cultured people at court (Cf. Valdés, 1997: 219-220; Lapesa, 1974: 16).

\section{5-That verse should be spoken in the same way as prose.}

Valdés thought that all linguistic construction, whether in verse or prose, should be close to normal language, real language use and therefore should be as simple as possible (Valdés, 1997: 249-250). 


\section{VALDÉS AND TRANSLATION}

The knowledge of language shown in his work Dialogue of Language, reflected in his Linguistic Proposals as outlined above, coupled with the academic training in Latin, Greek and Hebrew received at Alcalá University show Valdés fit to carry out translations.

Through this activity, Valdés also continues the humanist tradition and joins the list of humanist reformers who similarly carried out this type of work.

Valdés limits his translations to purely sacred texts prompted by his religious concerns. He carried out various translations: the complete Psalters, translated from Hebrew; a part of the Saint Matthew Gospel translated from the Greek and the Epistles of Saint Paul to the Romans and First Epistle to the Corinthians. In the Prologue to the Psalter, Valdés for the first time establishes the philological and hermeneutic basis that should govern sacred translations (Cf. Nieto, 1997: 510).

Although translation was not a significant part of his professional life, in the work given over to this field Valdés reveals some of his thoughts about this craft, as expressed in the following statements:

A work of translation should try to improve those previously translated texts that did not attain the necessary level of quality. This is the criteria applied by Valdés when translating the Psalter unlike other sacred books (Cf. Ricart, 1964: 135).

The translation must pay maximum respect to the original text, especially when dealing with sacred texts that demand much respect. This leads Valdés tostretch the Spanish language in order to keep the sense of the original text, as is pointed out in the Dedicatory Prologue to the Psalms (Cf. Ricart, 1964: 135). By this criterion, Valdés follows the translation tradition of Saint Jerome who maintains the literal translation (sensus literalis) for sacred texts, though this is not to be confused with slavish or pedestrian translations (Cf. Calvo, 1984: 71-72).

According to Valdés, translation is by no means an easy craft because of the natural difficulty arising from the variety of vocabulary in the languages involved, that of the original and that of the rendered version (Cf. Valdés, 1997: 235).

Finally, Valdés thought, as did all reformist humanists who tackled translation, that it shows temerity to attempt translation without a suitable level in the languages involved (Cf. Valdés, 1997: 235-326). It is lack of mastery of the two languages concerned that is the source of all the errors that potentially are produced in the process of converting one language to the other (Gadamer, 2005: 464). 


\section{THE INFLUENCE OF VALDÉS IN THE SPANISH VERSION OF THE 'BEAR'S BIBLE' (BIBLIA DEL OSO)}

Spain quickly joined the European tide of translating the Bible into the different vernacular languages through the work undertaken by Casiodoro de la Reina, with close collaboration from Cipriano de Valera, who also carried out the first revision. The result was known as the 'Bear's Bible'(Biblia del Oso) from the seal of its printer to thus ease its diffusion in Spain, rather than identify the author which would have hampered its spread. The original title is The Bible that is the sacred texts of the Old and New Testament / put into Spanish, 1569 (Basel, Switzerland, 1569). The entire Bible was translated into Castilian, a romance language, from its original Hebrew and Greek.

Both the translation's author, Casiodoro de la Reina and Cipriano de Valera were elderly monks of the Saint Jerome order in the Monastery of Saint Isidoro of Seville who had fled abroad to Geneva with almost the entire monastic community to save themselves from persecution by the Inquisition because of their proximity to Protestant reform doctrine. Travelling through various European countries (England, the Low Countries, France, Germany, Switzerland), publication of the Bible was finally made in Basel in 1569.

Different spiritual movements were forming in Spain from the end of the fourteenth into the beginning of the fifteenth century and this, combined with the influence of the doctrine and writings of Erasmus on the Peninsular, encouraged the desire for Church reform and familiarity with the Holy Scriptures. This new religious climate is characterized by both the growing movement in favour of Reform and the interest in translating the Bible into Castilian led by the Spanish reformers in exile. It is within this context that the Bear's Bible of Casiodoro de la Reina must be placed, as well as other important partial translations of the Bible known as Psalter of Valdés (1537), commented upon above, the New Testament of Francisco de Enzinas (1543), the Ferrara Bible that translates the so-called Hebrew Bible (1553), the New Testament of Juan Pérez (1556) and the Bible of Casiodoro de la Reina, revised by Cipriano de Valera (1602).

There can be no doubt that the work of Casiodoro de la Reina made a considerable contribution to the development and expansion of Castilian as a vernacular tongue in that previously there had only been partial translations of the Bible into Castilian, such as that of Ferrara. Although the translation of Casiodoro de la Reina was carried out outside Spain and printed in Basel, the seed of said project had been planted in Seville soil.

The first edition of the Bear's Bible was not widely distributed and it was hard to get hold of a copy. It was for this reason that Cipriano de 
Valera, who had participated in the first edition, undertook a second edition (1602), in the hope of giving it wider diffusion and at the same time revised the first edition text. In addition to the value of Valera's revision, his Introduction also has considerable interest in that it defends the need to have Bibles in the vernacular languages so that everyone can gain knowledge of the Word of God and thereby it favours the development of vernacular Castilian (Cf. González, 2001: XXVII).

The Bear's Bible of Casiodoro de la Reina was a milestone, not only because it was the first complete version of the Bible in Castilian, but also because it established linguistic and hermeneutic canons that passed into the humanist translation tradition and were also supported by the majority of reformers of the sixteenth century exile,

Juan de Valdés, linguist, reformist and Spanish exile, exerted considerable influence on Casiodoro de la Reina and Cipriano de Valera in their version of the Bible, as can be seen from the presence in the work of phrases and expressions from him and Francisco Enzinas. This influence is not surprising when we consider, as has been done above, the considerable contributions made by Valdés to the fields of language and translation.

\section{DISTINCTIVE CONTRIBUTIONS OF VALDÉS:}

Through his work Dialogue of Language and Linguistic Proposals, Spanish is put on a par with other languages, Latin included, by writing the work from the perspective of Castilian as a romance or modern language.

His work clearly demonstrates the literary and linguistic ideals of humanism.

While appreciating the literary form, priority is given to oral language use over literary, because of the naturalness and spontaneity of the spoken tongue. Sayings and dialogues are used to aid this.

The humanist tradition in translation is followed and Valdés joins the body of reformist humanists who also undertook this task.

As linguist, reformer and Spanish exile, he had considerable influence on Casiodoro de la Reina, author of the first complete version of the Bible in Castilian.

\section{BIBLIOGRAFÍA CITADA:}

ALCALÁ, Ángel, 1997: "Introducción”, en JUAN DE VALDÉS: Obras completas, I. Diálogos, Escritos espirituales. Cartas, Madrid: Ediciones de la Fundación José Antonio de Castro, IX-LXXXII. 
BARBOLANI, Cristina, 2006: "Introducción”, en JUAN DE VALDÉS: Diálogo de la lengua, Madrid: Ediciones Cátedra, 11-113.

BATAILLON, Marcel, 1986: Erasmo y España, México: Fondo de Cultura Económica.

CALVO, Juan José, 1984: Juan Luis Vives: ¿Un pionero de la traductología moderna? Apuntes sobre una discrepancia, en Quaderns de Filología: Miscelànea Sanchis Guarner, Valencia: Universitat de Valencia, Vol. 2.

GADAMER, Hans-Georg, 2005: Verdad y Método, Salamanca: Ediciones Sígueme.

GONZÁLEZ RUIZ, José María, 2001: “Introducción General”, en LA BIBLIA DEL OSO, Madrid: Taurus, XIII-XXIX.

LA BIBLIA DEL OSO, 2001: Madrid: Editorial Taurus.

LAPESA, RAFAEL, 1974: "Introducción (Selección, estudio y notas)", en JUAN DE VALDÉS: Diálogo de la lengua, Zaragoza: Editorial Ebro, 7-27.

NIETO, José Constantino, 1997: El Renacimiento y la otra España, Genève: Librairie Droz.

RICART, Domingo, 1964: "Transcripción, introducción y notas", enJUAN DE VALDÉS: Diálogo de Doctrina Christiana y el Salterio traducido del hebreo en romance castellano, México: Universidad Nacional Autónoma de México.

TERRACINI, Lore, 1993: "Nebrija y Valdés críticos literarios", en Gramática y Humanismo (Edición de Pedro Ruiz Pérez), Córdoba: Ayuntamiento de Córdoba, Ediciones libertarias, 145-162.

VALDÉS, Juan, 1997: "Diálogo de la lengua", en Obras Completas, I. Diálogos, Escritos espirituales. Cartas, Madrid: Ediciones de la Fundación José Antonio de Castro, 153-266. 